\title{
MOBİLYA İMALATI SEKTÖRÜNÜN FİNANSAL PERFORMANSININ ORAN ANALİZİ VE
} TOPSIS YÖNTEMIYLE DEĞERLENDIRILMESI

\section{Beyhan BELLER DİKMEN}

Dr. Öğr. Üyesi, Tarsus Üniversitesi, Uygulamalı Bilimler Fakültesi, Uluslararası Ticaret ve Lojistik Bölümü, Tarsus, Mersin, Türkiye. E-mail: b.beyhanbeller@gmail.com,

ORC-ID: 0000-0003-2260-6321 


\title{
MOBILLYA İMALATI SEKTÖRÜNÜN FINANSAL PERFORMANSININ ORAN ANALIZII VE TOPSIS YÖNTEMIYLE DEĞERLENDİRILMESI
}

\author{
ÖZ
}

İnsanların evlerinde ve işyerlerinde kullandıkları mobilyaların üretildiği mobilya imalatı sektörü, sanayinin önemli sektörlerinden biri olarak belirtilmektedir. Sektörün varlığını devam ettirebilmesi ve rekabet gücünü arttırabilmesi finansal performansına bağlı olarak gerçekleşmektedir. Bu nedenle, işletmeler ve sektörlerdeki finansal tablo analizlerinin doğru ve anlaşılır bir şekilde gerçekleştirilmesi, işletmelerin güçlü bir ekonomik yapısının olması açısından önem taşımaktadır. Bu kapsamda, Türkiye'de mobilya imalatı sektörünün finansal performansının analiz edilerek değerlendirilmesi amaçlanmıştır. Bu amaç doğrultusunda, mobilya imalatı sektöründe faaliyet gösteren işletmelerin 2009 - 2019 yıllarına ait verileri Türkiye Cumhuriyet Merkez Bankas1 (TCMB) Sektör Bilançolarından elde edilmiştir. Bu verilerin analizleri, oran analizi ve Topsis yöntemi aracıllı̆ı ile gerçekleştirilmiştir. Analiz sonuçlarına göre, mobilya imalatı sektörünün varlıklarını finanse ederken yararlandığ 1 kısa vadeli yükümlülüklerini yerine getirmek için yeterli hazır değerlere sahip olduğu, sektörün çalışma kapsamındaki tüm yıllarda düşük de olsa kâr elde ettiği tespit edilmiştir. Sektör performansının en iyi olduğu y1l 2019 yıll, en düşük seviyede olduğu yıl ise 2016 yılı olarak belirlenmiştir.

ANAHTAR KELIMELER: Finansal Performans, Mobilya İmalatı Sektörü, Sektör Bilançoları, Oran Analizi,

TOPSIS Yöntemi

JEL Kodları: M40, M41.

\section{EVALUATION OF THE FINANCIAL PERFORMANCE OF THE FURNITURE MANUFACTURING SECTOR BY RATIO ANALYSIS AND TOPSIS METHOD \\ ABSTRACT}

The furniture manufacturing sector, where the furniture used by people in their homes and workplaces are produced, is indicated as one of the important sectors of the industry. The sector's ability to survive and increase its competitive power depends on its financial performance. For this reason, accurate and comprehensible analysis of financial tables in businesses and sectors is important for businesses to have a strong economic structure. In this context, this study aimed to evaluate by analyzing the financial performance of the furniture manufacturing sector in Turkey. In line with this aim, the related data belong to the companies operating in the furniture manufacturing sector, between the years 2009 - 2019 were obtained from the Central Bank of the Republic of Turkey (CBRT) Sector Balance Sheets. The analysis of these data was carried out by ratio analysis and Topsis method. Based on the results of the analysis, it was determined that the furniture manufacturing sector has sufficient ready values to fulfill its short-term liabilities to use while financing its assets, and the sector made a low profit in all years within the scope of the study. The year with the best performance in the sector was determined as 2019 , and the year with the lowest level in 2016.

KEYWORDS: Financial Performance, Furniture Manufacturing Sector, Sector Balance Sheets, Ratio Analysis, TOPSIS Method.

JEL Codes: M40, M41. 


\section{GİRİ̧̧}

Sanayinin önemli sektörlerinden biri olan mobilya imalatı sektörü tarafından üretilen mobilyalar insanların hem evlerinde hem de işyerlerinde kullanılmaktadır. Mobilyalar, insanların oturma, uyuma, taşıma ve depolama gibi birçok ihtiyacını karşılamaktadır. Bu yüzden, mobilyalar insanların yaşamlarının her alanında karşılarına çıkan nesneler olarak ifade edilebilmektedir (Mutlu vd., 2012: 21). Yaşamın her alanında kullanılan mobilyaların seçilmesinde rahatlık ve görsellik müşteriler tarafından öncelikli olarak dikkate alınmaktadır. Bu nedenle sektördeki işletmelerin, müşteri beklentileri ve bu beklentilerin karşılanması ile oluşacak müşteri memnuniyetini de göz önünde bulundurarak mobilya imalatını gerçekleştirmesi gerekmektedir. Çünkü müșterilerin almış oldukları mobilyalardan memnun kalması ihtiyaç durumunda aynı işletmenin tercih edilmesini ve farklı kişilere bu ürünlerin önerilmesini sağlayacaktır. Bu öneriler doğrultusunda işletmeler, potansiyel müşterilerin taleplerini karşılayabilmek için mobilya üretimini gerçekleştirmektedir. Üretilen mobilyaların satışının gerçekleştirilmesi sonucunda işletmeler mali nitelikli işlemlerini kayıt altına alarak finansal tablolarını düzenlemektedir. Düzenlenen finansal tablolara çeşitli analiz yöntemlerinin uygulanması ile işletmelerin finansal performansları ile ilgili değerlendirmeler yapılabilmektedir.

İşletmelerin finansal performanslarının doğru ve anlaşılır bir şekilde değerlendirilmesi işletmelerin güçlü bir ekonomik yapısının olması açısından önem taşımaktadır. Aynı zamanda bu değerlendirmeler, işletme yöneticileri tarafından alınacak kararların da daha doğru olmasını sağlayabilmektedir. Bu nedenlerden dolayı, finansal performans değerlendirmesinde işletme faaliyetleri sonucunda düzenlenmiş olan finansal tablolar kullanılmaktadır. Finansal tablolar aracılığıyla işletmelerin likiditesinin, yükümlülüklerinin yerine getirilmesinin, verimliliğinin ve karlılığının değerlendirilmesi için oran analizi kullanılmaktadır (Stepanyan, 2014: 175). Sektörlerin ya da işletmelerin performans sıralamasını yapmak için ise Topsis yöntemi kullanılabilmektedir.

Bu kapsamda, Türkiye'de mobilya imalatı sektörünün finansal performansının analiz edilerek değerlendirilmesi çalışmanın amacını oluşturmaktadır. Bu amaç doğrultusunda çalışmada öncelikle konu ile ilgili literatürde bulunan çalışmalara yer verilmiştir. Daha sonra, mobilya imalatı sektöründe faaliyet gösteren işletmelere ait veriler Türkiye Cumhuriyet Merkez Bankası (TCMB) Sektör Bilançolarından elde edilerek verilerin oran analizi ve Topsis yöntemi aracıllı̆g ile analizleri yapılmıştır. Son olarak ise, sektöre ait analiz sonuçları ile ilgili değerlendirmelerde bulunulmuştur.

\section{LITERATÜR TARAMASI}

İmalat ve mobilya imalatı sektörünün yapısı ve bu sektördeki işletmelerin performanslarının değerlendirilmesi ile ilgili literatürde yerli ve yabancı çalışmalar bulunmaktadır. Bu kapsamda, seçilen çalışmalara Tablo 1'de yer verilmiştir.

Tablo 1: İmalat ve Mobilya İmalatı Sektörünün Performansları Üzerine Literatürde Yer Alan Çalışmalar

\begin{tabular}{|c|c|c|c|}
\hline $\begin{array}{c}\text { Yazarlar } \\
\text { (YII) }\end{array}$ & $\begin{array}{c}\text { Çalışmanın } \\
\text { Yöntemi }\end{array}$ & Çalışmanın Amacı ve Kapsamı & Çalışmanın Sonuçları \\
\hline $\begin{array}{l}\text { Uygurtürk } \\
\text { ve Korkmaz } \\
(2012)\end{array}$ & $\begin{array}{l}\text { Oran Analizi, } \\
\text { Topsis } \\
\text { Yöntemi }\end{array}$ & $\begin{array}{l}\text { Türkiye'de ana metal sanayi sektöründe } \\
\text { faaliyetlerini yerine getiren ve İMKB'de } \\
\text { işlem gören işletmelerin finansal } \\
\text { performanslarının analiz edilmesi } \\
\text { amaçlanmıştır. } \\
\text { İMKB'de işlem gören } 13 \text { ana metal sanayi } \\
\text { işletmesine ait } 2006 \text { - } 2010 \text { dönemleri ile } \\
\text { ilgili veriler analiz edilmiştir. }\end{array}$ & $\begin{array}{l}\text { Çalışma sonucunda, ana metal sanayi } \\
\text { sektöründe faaliyetlerini yerine getiren } \\
\text { işletmelerin analiz dönemine ait performans } \\
\text { puanlarının dalgalanma gösterdiği } \\
\text { belirlenmiştir. Yöntemin önerdiği yüksek } \\
\text { performans sıra değerine sahip olan } \\
\text { işletmelerde ortaya çıkan portföyün düşük } \\
\text { performans sıra değerine sahip olan } \\
\text { işletmelerden daha iyi getirisinin olduğu } \\
\text { tespit edilmiştir. }\end{array}$ \\
\hline $\begin{array}{l}\text { Kizılbudak } \\
\text { (2013) }\end{array}$ & Oran Analizi & 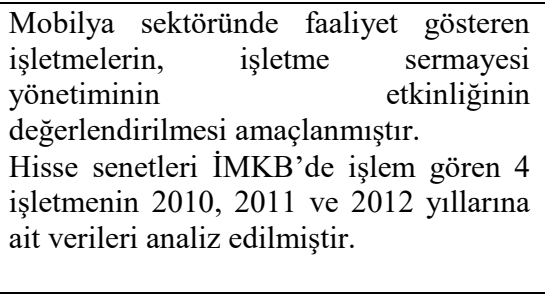 & $\begin{array}{l}\text { Çalışma sonucunda, mobilya sektöründeki } \\
\text { işletmelerin varlık yapılarında dönen varlık } \\
\text { yatırımlarının daha fazla olduğu, finansman } \\
\text { politikalarının kısa vadeli yabancı kaynak } \\
\text { kullanımı yönünde olduğu, likidite ve } \\
\text { kârlılık durumlarının paralel ve sınırda } \\
\text { olduğu, işletme sermayesinin yönetiminde } \\
\text { başarı derecesinin işletmelerin işletme }\end{array}$ \\
\hline
\end{tabular}




\begin{tabular}{|c|c|c|c|}
\hline & & & $\begin{array}{l}\text { sermayesini ne ölçüde etkin ve verimli } \\
\text { kullandığ } 1 \text { ile ilgili olduğu belirlenmiştir. }\end{array}$ \\
\hline $\begin{array}{l}\text { Traian } \\
\text { Ovidiu } \\
(2013)\end{array}$ & Oran Analizi & $\begin{array}{l}\text { Mobilya sektöründe mobilya üretimi ve } \\
\text { ticaretini yapan bir işletmenin finansal } \\
\text { performansının analiz edilmesi } \\
\text { amaçlanmıstır. } \\
2003 \text { y1lında kurulan S.C. Mobila S.R.L } \\
\text { işletmesinin } 2011 \text { - } 2012 \text { yıllarına ait } \\
\text { verileri analiz edilmiştir. }\end{array}$ & $\begin{array}{l}\text { Çalışma sonucunda, işletmenin dönen ve } \\
\text { duran varlıklarında düşüş olduğu, işletmenin } \\
\text { kâr tutarında azalış olmasına rağmen } \\
\text { özkaynaklarında artı̧̧ olduğu, kısa vadeli } \\
\text { yükümlülüklerde azalış olduğu } \\
\text { belirlenmiştir. Ciro açısından; mobilya } \\
\text { üretiminin yerel pazarda düştüğü mobilya } \\
\text { ticaretinin ise arttığı tespit edilmiştir. } \\
\text { İşletmenin hem brüt kârlılığı hem de net } \\
\text { kârlılığı azalmıştır. }\end{array}$ \\
\hline $\begin{array}{l}\text { Burja and } \\
\text { Marginean } \\
(2014)\end{array}$ & $\begin{array}{l}\text { Oran Analizi, } \\
\text { Korelasyon } \\
\text { Yöntemi }\end{array}$ & $\begin{array}{l}\text { Mobilya sektöründeki dupont modelinin } \\
\text { performansını etkileyebilecek faktörlerin } \\
\text { belirlenmesi amaçlanmıştır. } \\
\text { Mobilya sektöründe faaliyet gösteren beş } \\
\text { büyük işletmenin } 13 \text { yıllık verileri analiz } \\
\text { edilmiştir. }\end{array}$ & $\begin{array}{l}\text { Çalışma sonucunda, dupont modeli ile } \\
\text { analiz edilen finansal verilere göre ciro ve } \\
\text { net gelir, toplam varlıklar ve özkaynaklar ile } \\
\text { ilgili pozitif ilişkiler olabileceği tespit } \\
\text { edilmiştir. Çalışma kapsamında incelenen } \\
\text { dönemlerde işletmelerin önemli bir büyüme } \\
\text { eğilimi gösterdiği, sektördeki işletmelerin } \\
\text { varlıklarını iyileştirerek satışlarının } \\
\text { arttırlabileceği, dupont analizinin mobilya } \\
\text { sektöründeki işletmelerin performansların1 } \\
\text { etkileyen faktörleri belirlemede faydalı } \\
\text { olduğu belirlenmiştir. }\end{array}$ \\
\hline $\begin{array}{l}\text { Ömürbek ve } \\
\text { Mercan } \\
(2014)\end{array}$ & $\begin{array}{ll}\text { Topsis } & \text { ve } \\
\text { Electre } & \\
\text { Yöntemi } & \end{array}$ & $\begin{array}{l}\text { Topsis ve Electre yöntemleri ile imalat alt } \\
\text { sektörleri için belirlenen kriterlerin } \\
\text { dikkate alınarak en iyi performansa sahip } \\
\text { olan sektörün tespit edilmesi } \\
\text { amaçlanmıştır. } \\
\text { İmalat alt sektörlerinin TCMB tarafindan } \\
\text { yayınlanan 2009- } 2011 \text { sektör } \\
\text { bilançolarındaki verileri analiz edilmiştir. }\end{array}$ & $\begin{array}{l}\text { Çalışma sonucunda, topsis ve electre } \\
\text { yöntemlerine göre kok kömürü ve rafine } \\
\text { edilmiş petrol ürünleri imalatı sektörünün ilk } \\
\text { sırada yer aldığ belirlenmiştir. Diğer } \\
\text { sektörlerin siralamalarının birbirine çok } \\
\text { yakın olduğu tespit edilmiştir. }\end{array}$ \\
\hline $\begin{array}{l}\text { Akbulut } \\
\text { Rençber } \\
(2015)\end{array}$ & $\begin{array}{l}\text { Topsis } \\
\text { Yöntemi }\end{array}$ & $\begin{array}{l}\text { İşletme finansal performanslarının pazar } \\
\text { değeri/defter değeri oranı ile arasında } \\
\text { ilişki olup olmadığının araştırılması } \\
\text { amaçlanmıştır. } \\
\text { BIST’te işlem gören imalat sektöründeki } \\
32 \text { işletmenin } 2010-2012 \text { yıllarına ait } \\
\text { verileri analiz edilmiştir. }\end{array}$ & $\begin{array}{l}\text { Çalışma sonucunda, işletmelerin finansal ve } \\
\text { borsa performansları arasında istatistiksel } \\
\text { olarak anlamlı bir ilişki olmadığı tespit } \\
\text { edilmiştir. }\end{array}$ \\
\hline Baba (2017) & Oran Analizi & $\begin{array}{l}\text { Mobilya sektöründeki işletmelerin kâr } \\
\text { elde etme performansları açısından } \\
\text { varlıklarının finansal durumunun analiz } \\
\text { edilmesi amaçlanmıştır. } \\
\text { Romanya'da mobilya sektöründe faaliyet } \\
\text { gösteren } 15 \text { işletmenin } 2008 \text { - } 2016 \text { yılları } \\
\text { arasındaki finansal tablo verileri analiz } \\
\text { edilmiştir. }\end{array}$ & $\begin{array}{l}\text { Çalışma sonucunda, mobilya sektörünün } \\
2008 \text { - } 2012 \text { yılları arasında finansal getiri } \\
\text { oranının düştüğü, sonraki yıllarda ise bu } \\
\text { oranda artış meydana geldiği dört işletmenin } \\
2008-2011 \text { yılları arasında borçlanma } \\
\text { oranının yüksek olduğu belirlenmiştir. } \\
\text { Mobilya sektöründeki işletmelerde } \\
\text { ekonomik varlıkların bir bütün olarak } \\
\text { önemli derecede katma değer yaratabileceği } \\
\text { tespit edilmiştir. }\end{array}$ \\
\hline $\begin{array}{l}\text { Akyüz, } \\
\text { Y1ldırım ve } \\
\text { Akyüz } \\
(2017)\end{array}$ & Oran Analizi & $\begin{array}{l}\text { Orman ürünleri ve mobilya sanayi } \\
\text { sektörünün finansal performanslarının } \\
\text { analiz edilmesi amaçlanmıştır. } \\
\text { KAP ve BİST'te işlem gören orman } \\
\text { ürünleri ve mobilya sanayi sektöründe } \\
\text { faaliyetlerini yerine getiren } 4 \text { işletmenin } \\
2015 \text { ve } 2016 \text { yıllarına ait finansal } \\
\text { tabloları analiz edilmiştir. }\end{array}$ & $\begin{array}{l}\text { Çalışma sonucunda, yıllar itibariyle kısa } \\
\text { vadeli borçlanmalarda artış ve özkaynaklar } \\
\text { da ise azalış olduğu, maliyetlerde ortaya } \\
\text { çıkan artış ve finansal kaynakların dışarıdan } \\
\text { karşılanması sebebiyle katlanılan giderlerin } \\
\text { kâr marjlarını düşürdügüü belirlenmiştir. }\end{array}$ \\
\hline $\begin{array}{l}\ddot{\text { Ozztel }} \\
\text { Yavuz } \\
(2019)\end{array}$ & $\begin{array}{l}\text { Entropi } \\
\text { Tabanlı Topsis } \\
\text { Yöntemi }\end{array}$ & 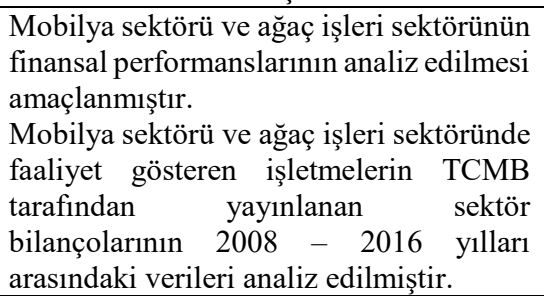 & $\begin{array}{l}\text { Çalışma sonucunda, mobilya ve ağaç işleri } \\
\text { sektörlerine ait başarı durumlarının yıllara } \\
\text { göre değiştiği tespit edilmiştir. Farkl } \\
\text { faktörlerin } \\
\text { performanslarını sektörlerin etkilediği ve her iki } \\
\text { sektörde de son } 3 \text { yılda performans } \\
\text { düşüklüğünün ortaya çıktığı belirlenmiştir. }\end{array}$ \\
\hline
\end{tabular}




\begin{tabular}{|c|c|c|c|}
\hline $\begin{array}{l}\text { Eyüboğlu ve } \\
\text { Bayraktar } \\
\text { (2019) }\end{array}$ & $\begin{array}{l}\text { AHP ve Topsis } \\
\text { Yöntemi }\end{array}$ & $\begin{array}{l}\text { Ana metal sanayi alt sektörlerinin finansal } \\
\text { performanslarının analiz edilmesi } \\
\text { amaçlanmıştır. } \\
\text { TCMB Reel Sektör Verileri Müdürlüğü } \\
\text { tarafından yayınlanan ana metal sanayi alt } \\
\text { sektörlerinin } 2014 \text { - } 2016 \text { yıllarına ait } \\
\text { verileri analiz edilmiștir. }\end{array}$ & $\begin{array}{l}\text { Çalışma sonucunda, } 2014-2016 \text { yılları } \\
\text { arasında çeliğin ilk işlenmesi aşamasında } \\
\text { elde edilen diğer ürünlerin imalat } \\
\text { sektörünün her yıl için en başarılı olduğu, en } \\
\text { başarısız sektörün ise ana demir ve çelik } \\
\text { ürünleri ile ferro alaşımların imalatı sektörü } \\
\text { olduğu tespit edilmiștir. }\end{array}$ \\
\hline
\end{tabular}

Çalışmada, mobilya imalatı sektörünün 2009 - 2019 yılları arasındaki finansal performansı oran analizi ve Topsis yöntemi aracılığıyla analiz edilmiştir. Çalışmada, TCMB Sektör sınıflamalarından mobilya imalatı sektörünün belirlenmesi ve bu sektöre ait 2009-2019 yıllarındaki verilerin kullanılması çalışmanın diğer çalışmalardan farkını oluşturmaktadır. Sektöre ait 11 yıllık verilerin kullanılması sektörün genel durumu ile ilgili olarak yorum yapılmasını sağlamaktadır. Bu nedenle, çalışmanın literatüre katkı sağlayacağı düşünülmektedir.

\section{MOBILYA IMMALATI SEKTÖRÜNE ILISSKIN FINANSAL PERFORMANSIN ORAN ANALIZİ VE TOPSIS YÖNTEMİ KULLANILARAK BELIRLENMESİ}

Çalışmanın bu kısmında mobilya imalatı sektörünün finansal performansının tespit edilmesi doğrultusunda çalışmanın amacı ve kapsamı, yöntemi ve verilerin analizine yer verilmiştir.

\section{1. Çalışmanın Amacı ve Kapsamı}

Çalışmanın amacı, Türkiye'de mobilya imalatı sektörünün finansal performansının analiz edilerek değerlendirilmesi olarak belirlenmiştir.

Çalışmada, TCMB'nin belirlemiş olduğu sektör sınıflamalarından C - İmalat ana sektörünün ikinci kademe alt sektörü olan C - 310 Mobilya İmalatı sektöründe faaliyet gösteren 6203 işletmenin 2009 - 2019 yıllarının konsolide bilanço ve gelir tablolarına ait verileri sektörün finansal performansının değerlendirilmesi için kullanılmıştır. TCMB'nin resmi internet sitesinde yayınlanmış olan sektör finansal tabloları, çalışmanın kapsamındaki işletmelerin gönüllülük esası doğrultusunda TCMB'ye gönderilen finansal tabloların konsolide edilmesi ile oluşmaktadır. Sektörde bulunan işletmelerin kimlik bilgilerinin gizli tutulması gerekliliğinden dolayı TCMB tarafından yayınlanmayan Borsa Performans Oranları hesaplanamamış ve bu oranlar çalışma kapsamı dışında tutulmuştur.

\section{2. Çalışmanın Yöntemi}

Çalışmada mobilya imalatı sektörünün finansal performansları oran analizi ve TOPSİS yöntemi kullanılarak değerlendirilmiştir. Analiz işlemi, sektöre ait konsolide bilanço ve gelir tablolarından faydalanılarak likidite, finansal yapı, varlık kullanım ve kârlılık oranlarının hesaplanması ile gerçekleştirilmiştir.

\subsubsection{Oran Analizi Yöntemi}

İşletmelerin düzenledikleri finansal tablolarda yer alan kalemler arasındaki ilişkilerin oranlar aracılığıyla değerlendirilmesini sağlayan yöntem oran analizi olarak ifade edilmektedir. Bu yöntemde oranlar, işletme faaliyetlerinin değerlendirilmesi açısından likidite, mali yapı, varlık kullanımı ve kârlılık oranları olarak gruplandırılmaktadır (Akdoğan ve Tenker, 2007: 640).

Likidite oranları, işletmede bulunan işletme sermayesinin yeterli olup olmadığının ve işletmelerin kısa vadeli borç ödeme güçlerinin belirlenmesi amacıyla kullanılmaktadır. Likidite oranları; cari oran, likidite (asit - test) oranı ve nakit oranı olarak sınıflandırılmaktadır (Akgüç, 1998: 23). Cari oran, işletmelerin vadesi gelen kısa vadeli yükümlülüklerinin yerine getirilmesi ile ilgili bilgi üretilmesini sağlayan oran olarak ifade edilmektedir (Moch vd., 2019: 6). Bu oranın genel kabul görmüş standart doğrultusunda gelişmiş ülkelerde 2 olmasının yeterli görülmesine rağmen gelişmekte olan ülkelerde ise 1,5 olmasının işletmelerin borç ödeme güçleri açısından olumlu olduğu belirtilmektedir (Çabuk ve Lazol, 2009: 208). Asit - test oranı, dönen varlıklardan stoklar kaleminin çıkarılarak kısa vadeli yabancı kaynaklara oranlanması sonucunda bulunan orandır. Bu oranın rakamsal olarak 1 olması kısa vadeli yükümlülüklerin yerine getirilmesi açısından genel kabul görmektedir. İşletmelerin acil durumlarda kullanabilmesi açısından para durumlarını yansıtan oran nakit oranı olarak ifade 
edilmektedir. Genel kabul görmüş standartlara göre nakit oranın 0,20 olması yeterli görülmektedir (Akdoğan ve Tenker, 2007: 647 - 649).

Mali yapı oranları, işletmelerin sahip olduğu varlıklarının ne kadarlık kısmının özkaynak ya da yabancı kaynaklarla karşılandığını belirlemek amacıyla kullanılmaktadır (Çabuk ve Lazol, 2009: 211). Çalışmada; kaldıraç oranı, özkaynaklar oranı, kısa vadeli yabancı kaynakların pasif toplamına oranı ve maddi duran varlıkların özkaynaklara oranı dikkate alınmıştır. Finansal kaldıraç oranı, işletmenin sahip olduğu aktiflerinin ne kadarlık bir oranda borçlanma yoluyla karşılandığının belirlenmesi için hesaplanan orandır. Hesaplanan bu oranın yüksek olması, özsermaye getiri oranını arttıracağı için ortaklar tarafından istenen bir durumdur. Fakat, kredi sağlayan kuruluşlar alacakları için emniyet payı özelliği taşıyacak öz varlıklarını belirlemek amacıyla bu oranın düşük olmasını istemektedir (Okka, 2006: 90). Finansal kaldıraç oranının gelişmiş ülkelerde \% 50'nin üzerine çıkmaması istenmesine rağmen gelişmekte olan ülkelerde bu oran çoğunlukla \% 60'1n üzerinde oluşmaktadır (Çabuk ve Lazol, 2009: 213). Özkaynakların, işletme kaynakları içerisindeki payını göstermek amacıyla özkaynaklar oranı dikkate alınmaktadır. Aynı zamanda bu oran, işletmenin uzun vadeli yükümlülüklerini yerine getirme gücünü göstermektedir. Özkaynaklar oranının yüksek olması, işletmenin uzun vadeli yükümlülüklerini ve bu yükümlülükler için hesaplanmış olan faiz tutarlarının ödenmesi ile ilgili zorluk yaşanmayacağını belirtmektedir (Akdoğan ve Tenker, 2007: 653). İşletmenin aktifinde yer alan varlıklarının kısa vadeli yabancı kaynaklarla finanse edilen kısmının belirlenmesi için kullanılan oran kısa vadeli yabancı kaynaklar oranıdır. Genel kabul görmüş standartlara göre bu oranın 1/3 seviyesini aşmaması istenmektedir (Çabuk ve Lazol, 2009: 213). Maddi duran varlıkların ne kadarlık kısmının özkaynaklarla finanse edildiğini gösteren oran ise maddi duran varlıkların özkaynaklara oranıdır. Genel kabul görmüş standartlara göre bu oranın 1'den küçük olması yeterli görülmektedir (Akdoğan ve Tenker, 2007: 657).

Varlık kullanım oranları, işletmelerin sahip oldukları varlıklarının işletme faaliyetlerinin yerine getirilmesi sırasında ne kadar etkili kullanıldığının tespit edilmesi aşamasında kullanılan oranlardır (Mashkour, 2019: 2). Çalışmada; alacak devir hızı, stok devir hızı, aktif devir hızı ve özkaynak devir hızı oranları dikkate alınmıştır. İşletmenin belirli bir dönemdeki alacaklarının yılda kaç defa tahsil edildiğini yani alacakların likiditesini gösteren oran alacak devir hızı oranıdır. Stok devir hızı ise, stokların kaç günde bir yenilendiğini göstermektedir (Çabuk ve Lazol, 2009: 221 - 223). İşletmeler sahip oldukları aktiflerinin verimliliğini belirlemek için aktif devir hızını kullanmaktadır. Bu oranın düşük olması işletmenin aktiflerini verimli kullanmadığını yani işletmede tam kapasite ile çalışılmadığını göstermektedir. İşletmelerin özkaynaklarının verimliliğini belirlemek için ise özkaynak devir hızı hesaplanmaktadır. Bu oran için genel kabul görmüşs standart bir oran bulunmamaktadır (Akdoğan ve Tenker, 2007: $667-668)$.

Kârlılık oranları, işletmelerin faaliyetleri sonucunda elde ettikleri kârlılığın yeterli olup olmadığının değerlendirilmesi aşamasında kullanılan oranlardır (Akgüç, 1998: 62). Çalışmada; brüt kâr marjı, faaliyet kâr marjı, dönem net kâr marjı, aktif kârlılık oranı ve özkaynak kârlılık oranı dikkate alınmıştır. İşletmede net satışların yüzde kaçının brüt satış kârı olduğunu belirlemek için brüt kâr marjının kullanılması gerekmektedir. $\mathrm{Bu}$ oran, bütün giderlerin karşılanması sonucu net kârın oluşumuna katkı sağladığı için oranın yüksek olması istenmektedir (Akdoğan ve Tenker, 2007: 669; Okka, 2006: 97). Faaliyet kâr marj1, işletmenin esas faaliyetlerinin kârlı olup olmadığının belirlenmesi için kullanılmaktadır. Oranın yüksek olması, işletmedeki esas faaliyetlerin kâr elde edilecek şekilde yerine getirildiğini göstermektedir. İşletme faaliyetlerinin net verimliliği ile ilgili bilgi veren oran net kâr marjıdır. Aktif kârlılık oranı, işletmedeki aktiflerin ne ölçüde kârlı kullanıldığını belirlemek için kullanılmaktadır (Çabuk ve Lazol, 2009: 231). İşletme sahip ya da ortaklarının işletmeye sağladıkları kaynakların verimli kullanılıp kullanılmadığını belirlemek için dikkate alınan oran ise özkaynak kârlılık oranıdır (Akdoğan ve Tenker, 2007: 671).

\subsubsection{TOPSİS Yöntemi}

TOPSIS yöntemi, Hwang ve Yoon tarafindan (1980) yılında ELECTRE yöntemine alternatif olarak geliştirilmiştir. Bu yöntem, performans derecelendirmelerinde karar vericilerden tek öznel girdi olarak ağırlıkları kullanmalarını istemektedir. Doğrusal özellik taşıyan bu ağırlıklar; eşit ağırlık, ağırlık merkezi ağırlıkları ve regresyon analizi sonucu elde edilen ağırlıklar şeklinde sınıflandırılmaktadır (Olson, 2004: 721). Birçok alanda kullanılan ve çok kriterli karar verme tekniklerinden biri olan TOPSIS 
yöntemi, alternatiflerin geometrik anlamda pozitif ideal çözümden en kısa uzaklığa ve negatif ideal çözümden en fazla uzaklığa sahip olma esasını dikkate almaktadır (Chen, 2000: 2). Yöntemdeki negatif ideal çözüm, uzaklaşılması gereken noktayı ifade etmekte, pozitif ideal çözüm ise karar noktalarının yakınlaşmasının istendiği nokta olarak belirtilmektedir (Uludağ ve Doğan, 2016: 26).

TOPSIS yöntemi altı ana adımdan oluşmakta ve bu adımlar aşağıdaki gibi sıralanmaktadır (Opricovic and Tzeng, 2004: 446; Jahanshahloo vd., 2006: 1545; Dashti vd., 2010; Aytekin ve Sakarya, 2013: 36):

1. Adım: Karar matrisinin oluşturulması,

2. Adım: Normalize edilmiş karar matrisinin oluşturulması,

3. Adım: Ağırlıklı normalize karar matrisinin oluşturulması,

4. Adım: İdeal ve negatif ideal çözümün belirlenmesi,

5. Adım: Ayrım ölçülerinin hesaplanması,

6. Adım: İdeal çözüme göreli yakınlığın hesaplanarak performans sıralamasının yapılmasıdır.

TOPSIS yönteminin uygulanmasında oluşturulması gereken adımlar aşağıda kısaca açıklanmıştır.

\section{Adım: Karar Matrisinin Oluşturulması}

TOPSIS yönteminin uygulanması sırasında ilk adımda karar verici tarafından oluşturulan ve başlangıç matrisi olarak da ifade edilen karar matrisinin oluşturulması yer almaktadır. Bu matrisin satırlarında üstünlükleri sıralanacak olan alternatifler, sütunlarında ise karar verirken kullanılacak olan değerlendirme kriterlerinin yer alması gerekmektedir. Buna göre, A karar matrisinde yer alan (m) alternatifleri, (n) ise değerlendirme kriterlerini ifade etmektedir. Bu doğrultuda oluşturulacak karar matrisi aşağıdaki gibi gösterilebilir (Ömürbek ve Kınay, 2013: 352):

$$
\mathrm{A}_{\mathrm{ij}}=\left[\begin{array}{cccc}
a_{11} & a_{12} & \ldots & a_{1 n} \\
a_{21} & a_{22} & \ldots & a_{2 n} \\
\ldots & \ldots & \ldots & \ldots \\
\ldots & \ldots & \ldots & \ldots \\
\ldots & \ldots & \ldots & \ldots \\
a_{m 1} & a_{m 2} & \ldots & a_{m n}
\end{array}\right]
$$

\section{Adım: Normalize Edilmiş Karar Matrisinin Oluşturulması}

A matrisinde yer alan elemanların kullanılması sonucu normalize edilmiş karar matrisi oluşturulmaktadır. Bu matrisin oluşturulmasında kullanılacak formül aşağıdaki gibidir (Bilici, 2019: 189):

$$
\begin{aligned}
R_{i j}= & \frac{a_{i j}}{\sqrt{\sum_{k=1}^{m} a_{k j}^{2}}} \\
& (\mathrm{i}=1, \ldots \mathrm{m}) \quad(\mathrm{j}=1, \ldots, \mathrm{n})
\end{aligned}
$$

Yukarıdaki formül kullanılarak oluşturulan normalize edilmiş karar matrisi aşağıdaki gibi gösterilebilir (Bilici, 2019: 189):

$$
\mathrm{R}_{\mathrm{ij}}=\left[\begin{array}{cccc}
r_{11} & r_{12} & \ldots & r_{1 n} \\
r_{21} & r_{22} & \ldots & r_{2 n} \\
\ldots & \ldots & \ldots & \ldots \\
\ldots & \ldots & \ldots & \ldots \\
\ldots & \ldots & \ldots & \ldots \\
r_{m 1} & r_{m 2} & \ldots & r_{m n}
\end{array}\right]
$$

\section{Adım: Ağırlıklı Normalize Karar Matrisinin Oluşturulması}

$\mathrm{Bu}$ adımda öncelikle değerlendirme kriterlerine ait ağırlık değerlerinin $\left(\mathrm{w}_{\mathrm{i}}\right)$ belirlenmesi gerekmektedir (Ömürbek ve Kınay, 2013: 353): 


$$
\sum_{i=1}^{n} w_{i}=1
$$

Yukarıdaki formül kullanılarak belirlenen ağırlık değerlerinin R matrisinin her bir sütununda yer alan elemanlar ile çarpılması sonucu ağırlıklı normalize karar matrisi oluşturulur. V matrisi olarak ifade edilen bu matris aşağıdaki gibi gösterilebilir (Ömürbek ve Kınay, 2013: 353):

$$
\mathrm{V}_{\mathrm{ij}}=\left[\begin{array}{cccc}
w_{1} r_{11} & w_{2} r_{12} & \ldots & w_{n} r_{1 n} \\
w_{1} r_{21} & w_{2} r_{22} & \ldots & w_{n} r_{2 n} \\
\ldots & \ldots & \ldots & \ldots \\
\ldots & \ldots & \ldots & \ldots \\
\ldots & \ldots & \ldots & \ldots \\
w_{1} r_{m 1} & w_{2} r_{m 2} & \ldots & w_{n} r_{m n}
\end{array}\right]
$$

\section{Adım: İdeal ve Negatif İdeal Çözümün Belirlenmesi}

Topsis yönteminin dördüncü adımı ideal ve negatif ideal çözümün belirlenmesinden oluşmaktadır. Bu adımda, değerlendirme faktörlerinin her birinin monoton bir şekilde artan ya da azalan bir eğilime sahip olduğu varsayılmaktadır. Burada ideal çözüme ulaşabilmek için ( $\mathrm{A}^{*}$ ) üçüncü adımda oluşturulmuş ağırlıklandırılmış normalize matrisin sütunlarının her birinde bulunan en düşük ve en yüksek değerler seçilmektedir (Uzun ve Kazan, 2016: 102).

$$
\begin{aligned}
& \mathrm{A}^{*}=\left\{(\max v i j / \mathrm{j} \in \mathrm{J}),\left(\operatorname{minvij} / \mathrm{j} \in J^{\prime}\right)\right\} \mathrm{i}=1,2,3, \ldots, \mathrm{m} \\
& \mathrm{A}^{-}=\left\{(\min v i j / \mathrm{j} \in \mathrm{J}),\left(\operatorname{maxvij} / \mathrm{j} \in J^{\prime}\right)\right\} \mathrm{i}=1,2,3, \ldots, \mathrm{m}
\end{aligned}
$$

Yukarıdaki denklemlerde J fayda kriterini, J' ise maliyet kriterini ifade etmektedir. Fayda kriteri için alternatifler arasındaki maksimum değerin belirlenmesi gerekmektedir. Maliyet kriteri için ise alternatifler arasındaki minimum değer belirlenmelidir. Belirlenen bu değerler sonucunda en çok tercih edilen alternatif $A^{*}$ ile en az tercih edilen alternatif ise $A^{-}$ile gösterilmektedir (Uzun ve Kazan, 2016: 102).

\section{Adım: Ayrım Ölçülerinin Hesaplanması}

Topsis yönteminde her bir karar noktasına ait değerlendirme kriteri değeri belirlenirken ideal ve negatif ideal çözüm setindeki sapmaların belirlenmesi gerekmektedir. Bu sapmaların belirlenmesi için Euclidian Uzaklık Yaklaşımı kullanılmaktadır. Elde edilen alternatiflere ait sapma değerleri İdeal Ayırım $\left(\mathrm{S}_{\mathrm{i}}{ }^{*}\right)$ ve Negatif İdeal Ayırım $\left(\mathrm{S}_{\mathrm{i}}{ }^{-}\right)$Ölçüsü olarak ifade edilmektedir. Bu ölçülere ait formüller aşağıdaki gibi gösterilebilir (Ömürbek ve Kınay, 2013: 354):

$$
\begin{aligned}
& \mathrm{S}_{\mathrm{i}}^{*}=\sqrt{\sum_{j=1}^{n}\left(v_{i j}-v_{j}^{*}\right)^{2}} \\
& \mathrm{~S}_{\mathrm{i}}{ }^{-}=\sqrt{\sum_{j=1}^{n}\left(v_{i j}-v_{j}^{-}\right)^{2}}
\end{aligned}
$$

Yukarıdaki formüller kullanılarak hesaplanacak $\left(\mathrm{S}_{\mathrm{i}}^{*}\right)$ ve $\left(\mathrm{S}_{\mathrm{i}}^{-}\right)$sayısı doğal olarak alternatif karar sayısı kadar meydana gelecektir (Ömürbek ve Kınay, 2013: 354).

\section{Adım: İdeal Çözüme Göreli Yakınlığın Hesaplanarak Performans Sıralamasının Yapilması}

TOPSIS yönteminin son adımında ideal çözüme göreli yakınlık hesaplanarak performans sıralaması yapılmaktadır. $\mathrm{Bu}$ adımda, her bir alternatifin ideal çözüme göreli yakınlığ $\left(\mathrm{C}_{\mathrm{i}}^{*}\right)$ hesaplanırken ideal ve negatif ayırım ölçüleri dikkate alınmaktadır. Buradaki ölçüt, negatif ideal ayrım ölçüsünün toplam ayırım ölçüsü içerisindeki payını belirtmektedir. Göreli yakınlık değerinin hesaplanması için kullanılacak formül aşağıdaki gibi gösterilmiştir (Ömürbek ve Kınay, 2013: 355):

$$
\mathrm{C}_{\mathrm{i}}^{*}=\frac{\mathrm{S}_{\mathrm{i}}^{-}}{\mathrm{S}_{\mathrm{i}}^{-}+\mathrm{S}_{\mathrm{i}}^{*}}
$$


Formülde belirtilen $\mathrm{C}_{\mathrm{i}}^{*}$ değeri $0 \leq \mathrm{C}_{\mathrm{i}}^{*} \leq 1$ aralığında değer almaktadır. $\mathrm{Bu}$ değer, $\mathrm{C}_{\mathrm{i}}^{*}=1$ ilgili karar noktasının ideal çözüme ve $\mathrm{C}_{\mathrm{i}}^{*}=0$ ilgili karar noktasının negatif ideal çözüme olan mutlak yakınlığını ortaya koymaktadır (Ömürbek ve Kınay, 2013: 355).

Elde edilen değerlerin büyüklük sırasına göre dizilmesi sonucu alternatiflerin önem sıraları belirlenerek performans sıralamaları yapılmış olacaktır.

\section{3. Çalışmanın Bulguları}

Çalışmanın bu bölümünde, Türkiye'deki mobilya imalatı sektörünün finansal tabloları oran analizi ve TOPSIS yöntemleri kullanılarak analiz edilmiştir. Bu işlem, sektöre ait konsolide bilanço ve gelir tablolarından faydalanılarak likidite, finansal yapı, varlık kullanım ve kârlılık oranlarının hesaplanması ile gerçekleştirilmiştir. Hesaplanan oranlar Tablo 2'de verilmiştir.

\subsubsection{Oran Analizi}

Çalışmanın bu kısmında, işletmelerin ve sektörlerin finansal performanslarının değerlendirilmesinde önem arz eden oran analizi yöntemi kullanılmıştır. Mobilya imalatı sektörünün finansal performansının değerlendirilmesi aşamasında hesaplanan oranlar, bu oranların hesaplanma amacı ve hesaplanma şekline Tablo 2'de yer verilmiştir.

Tablo 2: Mobilya İmalatı Sektörünün Finansal Performansının Değerlendirilmesinde Kullanılan Oranlar

\begin{tabular}{|c|c|c|}
\hline FÍNANSAL ORANLAR & HESAPLANMA AMACI & HESAPLANMA ȘEKLÍ \\
\hline \multicolumn{3}{|l|}{ Likidite Oranları } \\
\hline Cari Oran & \multirow{3}{*}{$\begin{array}{l}\text { Likidite oranları, işletmelerin kısa } \\
\text { vadeli borç ödeme gücünü ölçme ve } \\
\text { net işletme sermayelerinin yeterli } \\
\text { olup olmadiğının } \\
\text { değerlendirilmesinde kullanılır. }\end{array}$} & $\begin{array}{l}\text { Dönen Varliklar / K1sa Vadeli } \\
\text { Yabanc1 Kaynaklar }\end{array}$ \\
\hline Asit Test Oran1 & & $\begin{array}{l}\text { Dönen Varliklar - Stoklar / K1sa } \\
\text { Vadeli Yabanc1 Kaynaklar }\end{array}$ \\
\hline Nakit Oran1 & & $\begin{array}{l}\text { Hazır Değerler + Menkul Krymetler / } \\
\text { K1sa Vadeli Yabanc1 Kaynaklar }\end{array}$ \\
\hline \multicolumn{3}{|l|}{ Mali Yapı Oranları } \\
\hline $\begin{array}{l}\text { Yabancı Kaynak Oranı (Kaldıraç } \\
\text { Oranı) }\end{array}$ & \multirow{4}{*}{$\begin{array}{l}\text { Mali yap1 oranları, işletmelerin } \\
\text { varliklarının ne kadarlik kısmının } \\
\text { yabancı kaynaklarla ne kadarlik } \\
\text { kısmının öz kaynaklar ile finanse } \\
\text { edildiğini ve uzun vadeli borç ödeme } \\
\text { gücünün değerlendirilmesinde } \\
\text { kullanilır. }\end{array}$} & $\begin{array}{l}\text { Yabanc1 Kaynaklar Toplam1 / Pasif } \\
\text { Toplam1 }\end{array}$ \\
\hline Öz Kaynaklar Oranı & & Özkaynaklar Toplamı/ Pasif Toplamı \\
\hline $\begin{array}{l}\text { Kisa Vadeli Yabanc1 Kaynakların } \\
\text { Pasif Toplamina Oranı }\end{array}$ & & $\begin{array}{l}\text { K1sa Vadeli Yabanc1 Kaynaklar } \\
\text { Toplam1/Pasif Toplam1 }\end{array}$ \\
\hline $\begin{array}{lll}\text { Maddi Duran } & \text { Varlikların } & \bar{O} z \\
\text { Kaynaklara Oranı } & & \\
\end{array}$ & & $\begin{array}{l}\text { Maddi Duran Varliklar (Net) / } \\
\text { Özkaynaklar }\end{array}$ \\
\hline \multicolumn{3}{|l|}{ Varlık Kullanım Oranları } \\
\hline Alacak Devir $\mathrm{H}_{121}$ & \multirow{4}{*}{$\begin{array}{l}\text { Faaliyet oranları olarak da bilinen bu } \\
\text { oranlar, işletmelerin sahip olduğu ve } \\
\text { faaliyetlerini gerçekleştirmede } \\
\text { kullandiğı varliklarını ne ölçüde etkin } \\
\text { kullandiğının değerlendirilmesinde } \\
\text { kullanılır. }\end{array}$} & $\begin{array}{l}\text { Net Satışlar / Kısa Vadeli Ticari } \\
\text { Alacaklar + Uzun Vadeli Ticari } \\
\text { Alacaklar }\end{array}$ \\
\hline Stok Devir H1z1 & & Satışların Maliyeti / Stoklar \\
\hline Aktif Devir $\mathrm{H}_{121}$ & & Net Satışlar / Aktif Toplam1 \\
\hline Özkaynak Devir Hiz1 & & Net Satışlar / Özkaynaklar \\
\hline \multicolumn{3}{|l|}{ Karlılık Oranları } \\
\hline Brüt Kar Marj1 & \multirow{5}{*}{$\begin{array}{l}\text { Karlilik oranları, işletmelerin satı̧̧ları } \\
\text { ve diğer faaliyetlerini ne ölçüde karlı } \\
\text { gerçekleştirdiğini bir başka ifadeyle } \\
\text { işletmelerin ne ölçüde etkin } \\
\text { yönetildiğinin değerlendirilmesinde } \\
\text { kullanilır. }\end{array}$} & Brüt Satış Kar1/ Net Satışlar \\
\hline Faaliyet Kar Marj1 & & Faaliyet Kar1 / Net Satışlar \\
\hline Dönem Net Kar Marj1 & & Dönem Net Kar1 / Net Satışlar \\
\hline Aktif Karlilik Oranı & & Dönem Net Kar1 / Aktif Toplam1 \\
\hline Özkaynak Karlilik Oran1 & & Dönem Net Kar1 / Q̈zkaynaklar \\
\hline
\end{tabular}

Kaynak: Deran, İskenderoğlu ve Erduru, 2014: 949; Çabuk ve Lazol, 2009: 202 - 234.

Çalışmada Tablo 2'de yer alan oranlar, mobilya imalatı sektörünün 2009 - 2019 yılları için ayrı ayrı hesaplanmıştır. Çalışma kapsamında sektöre ait 176 oran hesaplanarak bu oranların değişimleri yıllar itibariyle değerlendirilmiştir. Elde edilen oranlar, ticari gelenekler sonucunda ortaya çıan standart oranlarla karşılaştırılmış ve sektöre ait finansal durum yorumlanmaya çalış1lmıştır. 
Mobilya imalatı sektörünün 2009 - 2019 y1llarındaki kısa vadeli borç ödeme gücünün ve çalışma sermayesinin yeterliliğini belirleyebilmek için hesaplanan cari oran, likidite oranı ve nakit oranlarına ait veriler Grafik 1'de verilmiştir.

Grafik 1: Mobilya İmalatı Sektörünün Likidite Oranlarının Yıllar İtibariyle Gelişimi

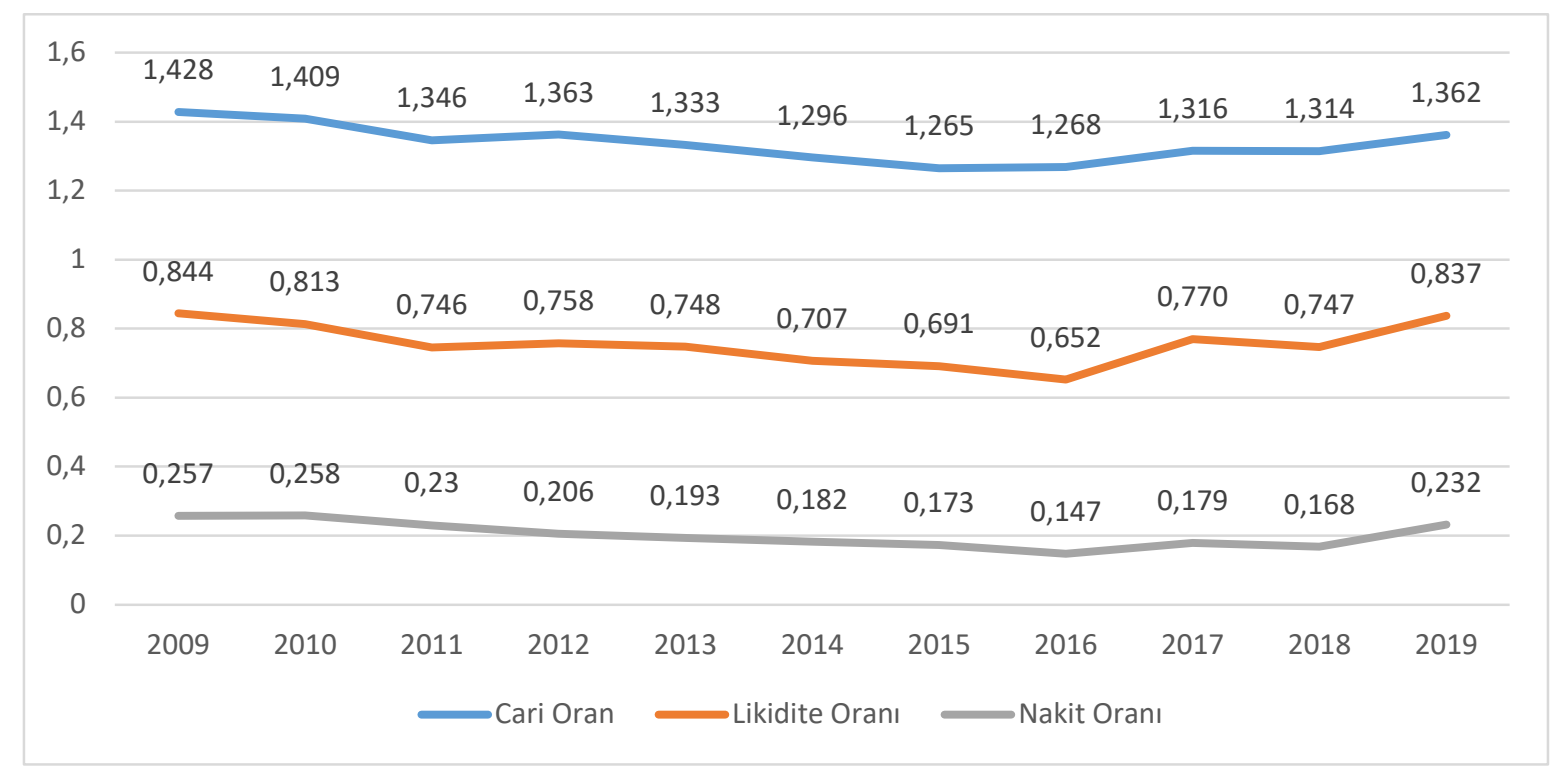

Grafik 1'de yer alan verilere göre, mobilya imalatı sektörünün cari oran değerleri yıllar itibariyle 1,265 ile 1,428 değerleri arasında değişiklik göstermektedir. Grafikte yer alan değerler, çalışma kapsamındaki yıllar itibariyle mobilya imalatı sektöründe genel kabul görmüş oranın altında cari oran değerlerinin oluştuğunu göstermektedir. Bu durum, genel olarak sektörün kısa vadeli yükümlülüklerini yerine getirirken zorlandığ 1 şeklinde ifade edilebilmektedir. Grafik 1'deki verilere göre sektörün likidite oranları yıllar itibariyle 0,652 ile 0,844 arasında değişmektedir. Elde edilen oranlar, likidite oranları açısından genel kabul görmüş oran olan 1'in altındadır. Bu veriler, mobilya imalatı sektöründe stokların elden çıkarılamadığı yıllarda kısa vadeli yükümlülüklerin ödenmesinde güçlükler yaşandığını göstermektedir. Likidite oranları arasında en hassas oran olarak ifade edilen oran nakit oranıdır. Grafik 1'deki verilere göre mobilya imalatı sektörünün nakit oranına ait değerler 0,147 ile 0,258 arasında değişiklik göstermektedir. 2009 - 2013 yılları arasında ve 2019 yılında sektörün nakit oran değerleri genel kabul görmüş oranın üzerinde gerçekleşmiştir. Bu yıllarda mobilya imalatı sektörünün mevcut hazır değer yapısı güçlü ve sektör kısa vadeli yükümlülüklerini karşılayabilmektedir. 2013 - 2018 yılları arasında ise ortaya çıkan değerler genel kabul görmüş oranın altında kalmıştır. Sektörün bu yıllarda satışlarının durması ve alacaklarını tahsil edememesi durumunda kısa vadeli yükümlülükleri yerine getirmede zorlandığı şeklinde yorumlanabilir.

Mobilya imalatı sektörünün likidite oranlarının değerlendirilmesinden sonra mali yapı oranlarına ait değerler Grafik 2'de gösterilmiştir. 
Mobilya İmalatı Sektörünün Finansal Performansının Oran Analizi ve Topsis Yöntemiyle Değerlendirilmesi

Grafik 2: Mobilya İmalatı Sektörünün Mali Yapı Oranlarının Yıllar İtibariyle Gelişimi

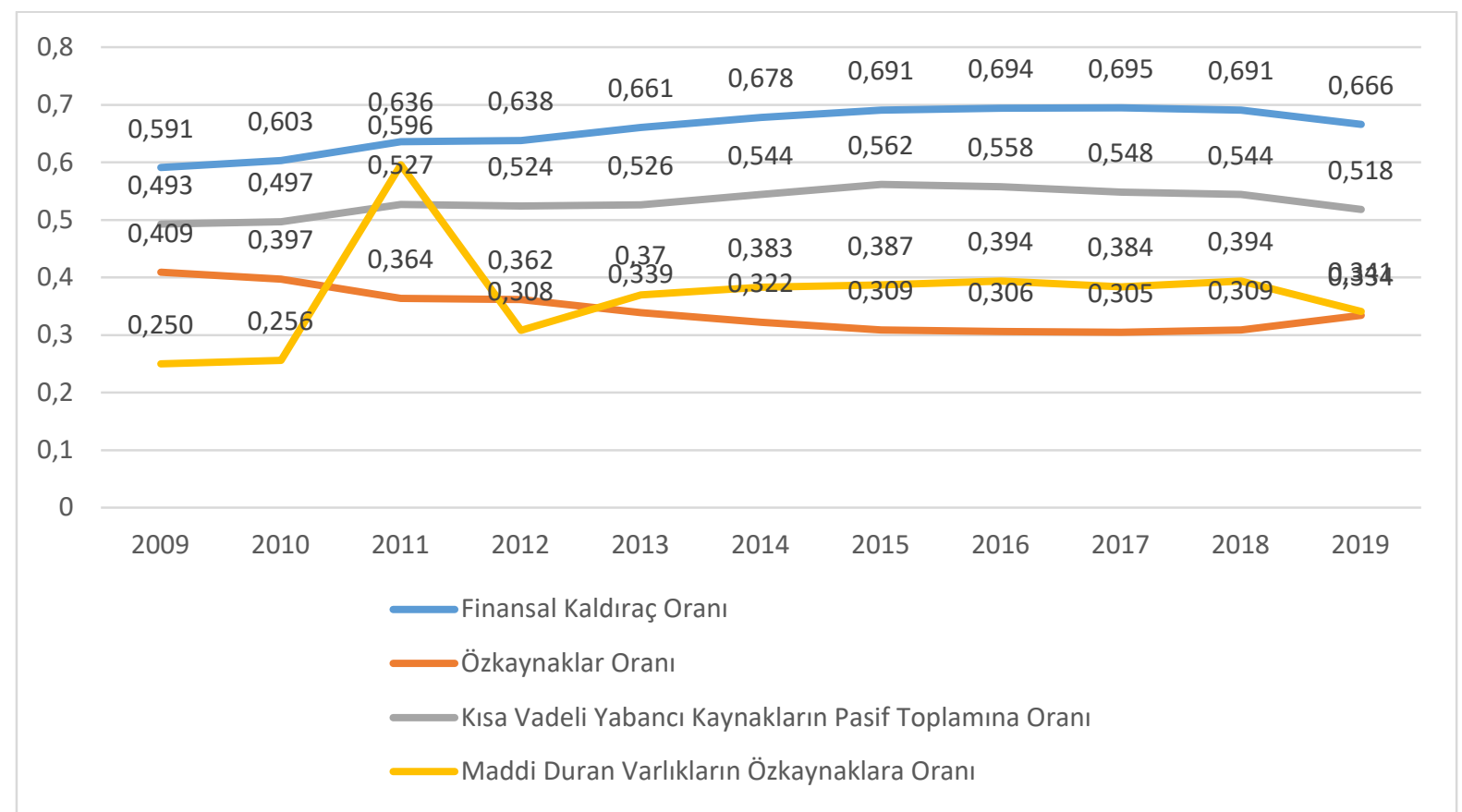

Grafik 2'de yer alan bilgilere göre mobilya imalatı sektörünün finansal kaldıraç oranları 0,591 - 0,695 değerleri arasında değişiklik göstermektedir. Sektörün 2009 - 2019 yıllarında finansal kaldıraç oran değerlerinin \% 50'nin üzerinde olduğu belirlenmiştir. $\mathrm{Bu}$ durum, sektörün sahip olduğu varlıklarının finanse edilmesinde çoğunlukla yabancı kaynaklarını kullandığı şeklinde ifade edilmektedir. Özkaynak oranına ait değerler de finansal kaldıraç oran değerlerini tamamlayan bir şekilde gerçekleşmiştir. Grafikteki verilere göre sektörün kısa vadeli yabancı kaynaklarının pasif toplamına oranının \% 50 civarında olması dengeli bir finansman politikasına sahip olduğunu göstermektedir. Maddi duran varlıkların özkaynaklarla karşılanma oranı yıllar itibariyle 0,250-0,596 değerleri arasında değişmektedir. Bu değerler doğrultusunda, sektörün en düşük oranla 2009 yılında maddi duran varlık alımlarını özkaynakları ile finanse ettiği ifade edilebilir. Sektörün en yüksek oranla ise 2011 yılındaki maddi duran varlık alımlarının yaklaşık \% 60'lık kısmının özkaynaklarla finanse edildiği belirtilebilir.

Sektörün likidite ve mali yapı oranlarının değerlendirilmesinden sonra varlık kullanım oranlarına ait değerler Grafik 3’te gösterilmiştir. 
Mobilya Imalatı Sektörünün Finansal Performansının Oran Analizi ve Topsis Yöntemiyle Değerlendirilmesi

Grafik 3: Mobilya İmalatı Sektörünün Varlık Kullanım Oranlarının Yıılar İtibariyle Gelişimi

\begin{tabular}{|c|c|c|c|c|c|c|c|c|c|c|c|}
\hline 4,500 & & 3,880 & 4,044 & & & & & & & \multirow[b]{2}{*}{3,469} & \multirow[b]{2}{*}{$\begin{array}{c}3,640 \\
\end{array}$} \\
\hline 4,000 & & & & 3,669 & 3,412 & 3,408 & 3,276 & 3,152 & 3,350 & & \\
\hline 3,000 & \multirow{2}{*}{$\begin{array}{l}2,699 \\
2,403\end{array}$} & & \multirow{2}{*}{$\begin{array}{r}2,570 \\
2,350 \\
\end{array}$} & \multirow{2}{*}{$\begin{array}{l}2,507 \\
2,304\end{array}$} & \multirow{2}{*}{$\begin{array}{l}2,557 \\
2,245\end{array}$} & 2,663 & 2,667 & \multirow{2}{*}{2,529} & 880 & 2,944 & \multirow{2}{*}{$z_{3}, 7 \theta \bar{b}$} \\
\hline 2,500 & & 2,258 & & & & 2,139 & 2,031 & & & 2,379 & \\
\hline 1,500 & 0,982 & 0,892 & 0,937 & 0,907 & 0,868 & 0,857 & 0,825 & 0,775 & 0,879 & 0,910 & 0,919 \\
\hline 0,500 & & & & & & & & & & & \\
\hline 0,000 & 2009 & 2010 & 2011 & 2012 & 2013 & 2014 & 2015 & 2016 & 2017 & 2018 & 2019 \\
\hline & $\Rightarrow A$ & ak Devi & & Stok & vir Hızı & $\longrightarrow$ & if Devir & & Öz Ka & ak Devir & \\
\hline
\end{tabular}

Grafik 3'te yer alan bilgiler doğrultusunda mobilya imalatı sektörünün stok devir hızının çalışma kapsamındaki bazı yıllarda artış bazı yıllarda ise düşüş eğiliminde olduğu görülmektedir. Stok devir hızı değerleri, rakamsal olarak 1,7 - 2,7 arasında değişmektedir. Sektör, değer olarak $133-214$ gün aralığında stok devrini gerçekleştirmektedir. Grafik 3'teki verilere göre sektör, alacaklarını yılda ortalama 3 - 4 kez tahsil etmektedir. Sektörün alacak tahsil süresi 88 - 115 gün arasında değişiklik göstermektedir. Sektörün varlıklarının kaç katı satış yapıldığını belirlemek amacıyla kullanılan aktif devir hızı oranının 2009 - 2019 aralığında 0,77 ile 0,98 arasında değişiklik gösterdiği tespit edilmiştir. Bu değerler, sektörün sahip olduğu varlıklarının altında satış yapıldığı şeklinde ifade edilebilir. Mobilya imalatı sektörünün özkaynak devir hızı değerleri incelendiğinde, değerlerin 2,2 - 2,9 arasında değiştiği görülmektedir. Grafik 3’teki verilere göre, sektörün özkaynaklarını 2010, 2012 ve 2016 yılları hariç diğer yıllarda daha verimli kullandığg şeklinde yorumlanabilir.

Mobilya imalatı sektörünün finansal performansının değerlendirilmesinde son oran türü olan kârlılık oranlarına ait değerler Grafik 4'te gösterilmiştir.

Grafik 4: Mobilya İmalatı Sektörünün Kârlılık Oranlarının Yıllar İtibariyle Gelişimi

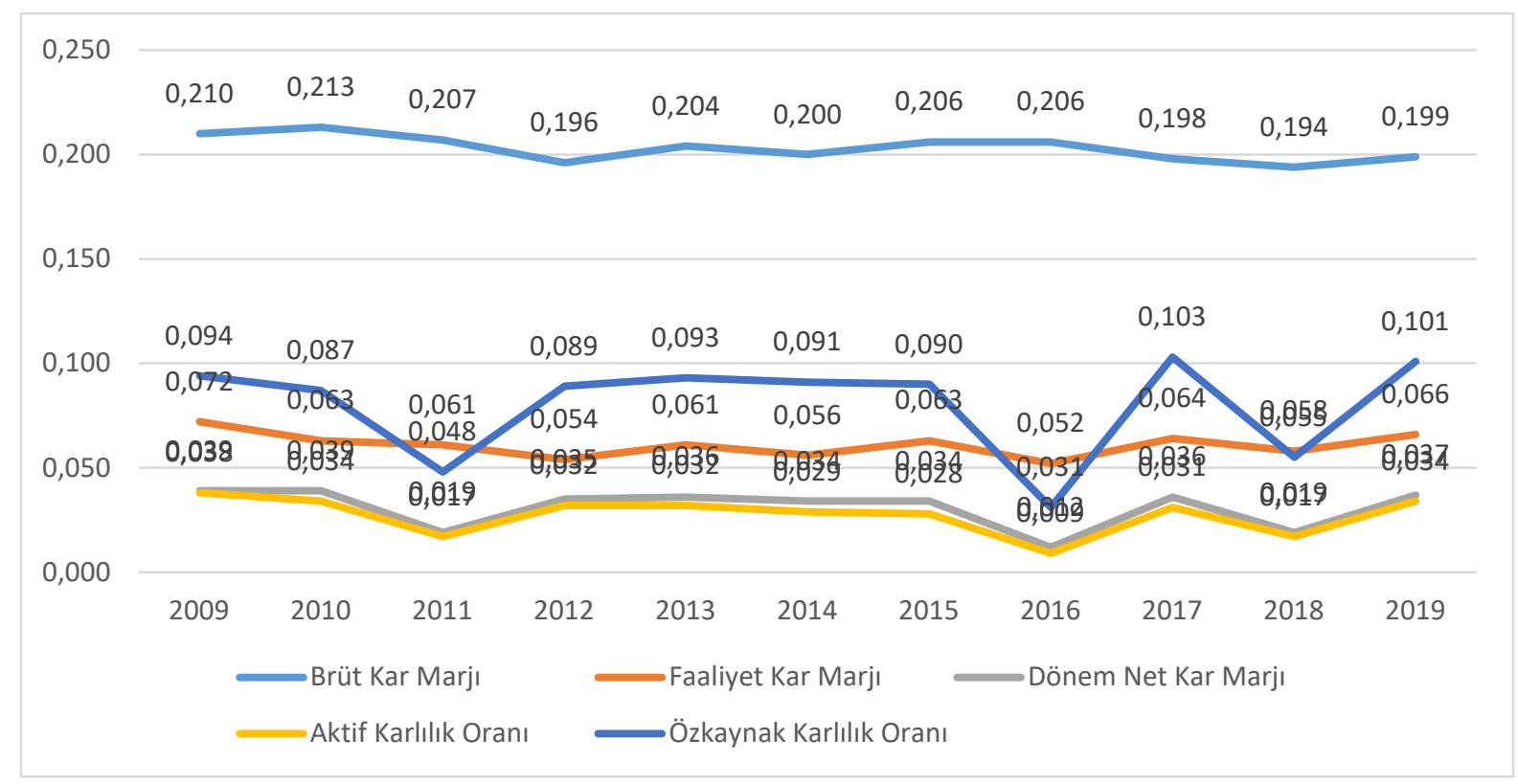

Grafik 4'te yer alan bilgilere göre mobilya imalatı sektörünün brüt kâr marjı değerlerinde 2009 - 2019 yılları arasında artış ve azalışlar ortaya çıkmıştır. Değerlerdeki artışların, sektördeki satış 
maliyetlerinin düşmesi ya da satışların yükselmesinden kaynaklanabileceği ifade edilebilir. Sektörün faaliyet kâr marjı değerleri \%05 ile \%07 arasında değişiklik göstermektedir. Sektörün gelir tablosu incelendiğinde faaliyet kar marjında yaşanan değişimin yıllar itibariyle artan seviyede pazarlama, satış ve dağıtım giderlerine katlanmasından kaynaklandığı belirlenmiş̧ir. Sektördeki faaliyetlerin net verimliliğinin değerlendirilmesinde kullanılan net kâr marjı değerlerine göre ise mobilya imalatı sektörü, çalışma kapsamındaki tüm yıllarda düşük de olsa kâr elde etmiştir. Sektörün gelir tablosu incelendiğinde yıllar itibariyle oluşan kambiyo zararlarının ve kısa vadeli borçlanma giderlerinin yüksek olması durumunun işletmenin karlılığının düşmesinde önemli bir etken olduğu görülmüştür. Sektörün aktif kârlılık oranı da net kâr marjı değerlerine paralel olarak gerçekleşmiştir. Mobilya imalatı sektöründe özkaynakların ne ölçüde verimli kullanıldığının belirlendiği oran olan özkaynak kârlılık oranı yıllar itibariyle $\% 03$ ve $\% 10$ arasında değişiklik göstermiştir. Bu veriler doğrultusunda, sektörün özkaynaklarını diğer yıllara göre 2017 ve 2019 yıllarında daha verimli kullandığı ifade edilebilir.

\subsubsection{TOPSİS Analizi}

Çalışmanın bu kısmında, çok kriterli karar verme yöntemlerinden biri olan ve pozitif ideal çözümden en kısa uzaklığa ve negatif ideal çözümden en fazla uzaklığa sahip alternatiflerin değerlendirilmesini gerektiren TOPSIS yöntemi kullanılmıştır. Çalışmada, finansal performans değerlendirmesinde sıklıkla kullanılan oranlar tercih edilmiştir (Ömürbek ve Kınay, 2013: 356). Çalışmada kullanılan finansal performans göstergeleri ve bu göstergelere ait kodlar Tablo 3'te gösterilmiştir.

Tablo 3: Çalışma Kapsamında Kullanılan Finansal Performans Göstergeleri ve Kodları

\begin{tabular}{|c|c|c|}
\hline Ana Oranlar & Alt Oranlar & Kodlar \\
\hline \multirow{3}{*}{ Likidite Oranları } & Cari Oran & L1 \\
\hline & Likidite Oranı & L2 \\
\hline & Nakit Oranı & L3 \\
\hline \multirow{4}{*}{ Mali Yapı Oranları } & Finansal Kaldıraç Oranı & M1 \\
\hline & Ozkaynaklar Oranı & $2 / 2$ \\
\hline & Kısa Vadeli Yabancı Kaynakların Pasif Toplamma Oranı & $2 / 3$ \\
\hline & Maddi Duran Varlıkların Ozkaynaklara Oranı & M4 \\
\hline \multirow{4}{*}{ Varlık Kullanım Oranları } & Alacak Devir Hızı & V1 \\
\hline & Stok Devir Hızı & $\sqrt{2}$ \\
\hline & Aktif Devir Hızı & V3 \\
\hline & Ozkaynak Devir Hızı & V4 \\
\hline \multirow{5}{*}{ Karlılık Oranları } & Brüt Kar Marji & K1 \\
\hline & Faaliyet Kar Marj1 & $\mathrm{K} 2$ \\
\hline & Dönem Net Kar Marj1 & $\mathrm{K} 3$ \\
\hline & Aktif Karlılik Oramı & $\mathrm{K} 4$ \\
\hline & Ozkaynak Karlılık Oranı & $\mathrm{K} 5$ \\
\hline
\end{tabular}

Çalışmada Tablo 2'de yer alan oranlara ait olarak belirlenmiş kodlar kullanılacaktır. Altı adımdan oluşan TOPSİS yönteminin üçüncü adımında ağırlıklı normalize karar matrisinin düzenlenebilmesi için ağırlıklandırma vektörünün kullanılması gerekmektedir. $\mathrm{Bu}$ vektörün belirlenmesinde çalışmanın teori kısmında da belirtildiği gibi eşit ağırlık, ağırlık merkezi ağırlıkları ve regresyon analizi sonucu elde edilen ağırlıklardan biri kullanılabilmektedir. Çalışmada, mobilya sektörünün finansal performanslarının değerlendirilmesi aşamasında kullanılacak performans göstergelerinin ağırlıkları eşit olarak dikkate alınmış ve hesaplamalar bu doğrultuda yapılmıştır.

TOPSIS yönteminde mobilya sektörü için yapılan değerlendirmeler Microsoft Office Excel 2013 programı kullanılarak hesaplamalar yapılmış ve süreç 6 adımda gerçekleştirilmiştir. Tablo 4 'te görüldüğü gibi 11 karar noktası ve 16 adet finansal orandan oluşan değerlendirme kriterleri kullanılmıştır. Birinci adımda (11x19) boyutlu olarak oluşturulan karar matrisleri Tablo 4'te gösterilmiştir (Eyüboğlu ve Bayraktar, 2019: 6 - 10): 
Tablo 4: Mobilya Sektörünün Karar Matrisleri

\begin{tabular}{|c|c|c|c|c|c|c|c|c|c|c|c|c|c|c|c|c|}
\hline Yillar & L1 & L2 & $\mathbf{L 3}$ & M1 & M2 & M3 & M4 & V1 & V2 & V3 & V4 & K1 & K2 & K3 & K4 & K5 \\
\hline 2009 & 1,428 & 0,844 & 0,257 & 0,591 & 0,409 & 0,493 & 0,250 & 4,063 & 2,699 & 0,982 & 2,403 & 0,210 & 0,072 & 0,039 & 0,038 & 0,094 \\
\hline 2010 & 1,409 & 0,813 & 0,258 & 0,603 & 0,397 & 0,497 & 0,256 & 3,880 & 2,370 & 0,892 & 2,250 & 0,213 & 0,063 & 0,039 & 0,034 & 0,087 \\
\hline 2011 & 1,346 & 0,746 & 0,230 & 0,636 & 0,364 & 0,527 & 0,596 & 4,044 & 2,350 & 0,937 & 2,570 & 0,207 & 0,061 & 0,019 & 0,017 & 0,048 \\
\hline 2012 & 1,363 & 0,758 & 0,206 & 0,638 & 0,362 & 0,524 & 0,308 & 3,669 & 2,304 & 0,907 & 2,507 & 0,196 & 0,054 & 0,035 & 0,032 & 0,089 \\
\hline 2013 & 1,333 & 0,748 & 0,193 & 0,661 & 0,339 & 0,526 & 0,370 & 3,412 & 2,245 & 0,868 & 2,557 & 0,204 & 0,061 & 0,036 & 0,032 & 0,093 \\
\hline 2014 & 1,296 & 0,707 & 0,182 & 0,678 & 0,322 & 0,544 & 0,383 & 3,408 & 2,139 & 0,857 & 2,663 & 0,200 & 0,056 & 0,034 & 0,029 & 0,091 \\
\hline 2015 & 1,265 & 0,691 & 0,173 & 0,691 & 0,309 & 0,562 & 0,387 & 3,276 & 2,031 & 0,825 & 2,667 & 0,206 & 0,063 & 0,034 & 0,028 & 0,090 \\
\hline 2016 & 1,268 & 0,652 & 0,147 & 0,694 & 0,306 & 0,558 & 0,394 & 3,152 & 1,790 & 0,775 & 2,529 & 0,206 & 0,052 & 0,012 & 0,009 & 0,031 \\
\hline 2017 & 1,316 & 0,770 & 0,179 & 0,695 & 0,305 & 0,548 & 0,384 & 3,350 & 2,353 & 0,879 & 2,880 & 0,198 & 0,064 & 0,036 & 0,031 & 0,103 \\
\hline 2018 & 1,314 & 0,747 & 0,168 & 0,691 & 0,309 & 0,544 & 0,394 & 3,469 & 2,379 & 0,910 & 2,944 & 0,194 & 0,058 & 0,019 & 0,017 & 0,055 \\
\hline 2019 & 1,362 & 0,837 & 0,232 & 0,666 & 0,334 & 0,518 & 0,341 & 3,640 & 2,706 & 0,919 & 2,747 & 0,199 & 0,066 & 0,037 & 0,034 & 0,101 \\
\hline
\end{tabular}

Karar matrislerinin oluşturulmasından sonra yöntemin ikinci adımında oran değerlerinin normalizasyonu gerçekleştirilerek normalize edilmiş karar matrisi elde edilmiş ve bu matris Tablo 5'te gösterilmiştir.

Tablo 5: Mobilya Sektörünün Normalize Edilmiş Karar Matrisleri

\begin{tabular}{|c|c|c|c|c|c|c|c|c|c|c|c|c|c|c|c|c|}
\hline Yillar & L1 & L2 & $\mathbf{L 3}$ & M1 & M2 & M3 & M4 & V1 & $\mathbf{V 2}$ & $\mathbf{V 3}$ & V4 & K1 & K2 & K3 & K4 & K5 \\
\hline 2009 & 0,322 & 0,336 & 0,377 & 0,270 & 0,359 & 0,280 & 0,199 & 0,341 & 0,351 & 0,333 & 0,277 & 0,312 & 0,355 & 0,365 & 0,399 & 0,340 \\
\hline 2010 & 0,318 & 0,323 & 0,379 & 0,276 & 0,349 & 0,282 & 0,203 & 0,326 & 0,308 & 0,303 & 0,259 & 0,316 & 0,311 & 0,365 & 0,357 & 0,315 \\
\hline 2011 & 0,303 & 0,297 & 0,338 & 0,291 & 0,320 & 0,299 & 0,473 & 0,340 & 0,305 & 0,318 & 0,296 & 0,307 & 0,301 & 0,178 & 0,179 & 0,174 \\
\hline 2012 & 0,307 & 0,302 & 0,302 & 0,292 & 0,318 & 0,297 & 0,245 & 0,308 & 0,299 & 0,308 & 0,289 & 0,291 & 0,266 & 0,328 & 0,336 & 0,322 \\
\hline 2013 & 0,301 & 0,298 & 0,283 & 0,302 & 0,298 & 0,298 & 0,294 & 0,287 & 0,292 & 0,295 & 0,295 & 0,303 & 0,301 & 0,337 & 0,336 & 0,336 \\
\hline 2014 & 0,292 & 0,281 & 0,267 & 0,310 & 0,283 & 0,309 & 0,304 & 0,286 & 0,278 & 0,291 & 0,307 & 0,297 & 0,276 & 0,318 & 0,305 & 0,329 \\
\hline 2015 & 0,285 & 0,275 & 0,254 & 0,316 & 0,271 & 0,319 & 0,307 & 0,275 & 0,264 & 0,280 & 0,307 & 0,306 & 0,311 & 0,318 & 0,294 & 0,325 \\
\hline 2016 & 0,286 & 0,259 & 0,216 & 0,317 & 0,269 & 0,317 & 0,313 & 0,265 & 0,233 & 0,263 & 0,291 & 0,306 & 0,256 & 0,112 & 0,095 & 0,112 \\
\hline 2017 & 0,297 & 0,306 & 0,263 & 0,318 & 0,268 & 0,311 & 0,305 & 0,281 & 0,306 & 0,298 & 0,332 & 0,294 & 0,316 & 0,337 & 0,326 & 0,373 \\
\hline 2018 & 0,296 & 0,297 & 0,247 & 0,316 & 0,271 & 0,309 & 0,313 & 0,291 & 0,309 & 0,309 & 0,339 & 0,288 & 0,286 & 0,178 & 0,179 & 0,199 \\
\hline 2019 & 0,307 & 0,333 & 0,341 & 0,304 & 0,293 & 0,294 & 0,271 & 0,306 & 0,352 & 0,312 & 0,316 & 0,295 & 0,325 & 0,346 & 0,357 & 0,365 \\
\hline
\end{tabular}


Normalize edilmiş karar matrisinin oluşturulmasından sonra yöntemin üçüncü adımında ağırlıklı normalize karar matrisinin düzenlenmesi gerekmektedir. Bu doğrultuda ağırlıklandırma ișleminin yapılabilmesi için ağırlıklandırma vektörü ${ }^{1}$ kullanılmıștır. Bu vektörün kullanılması ile olușturulan ağırlıklı normalize karar matrisi Tablo 6'da gösterilmiştir.

Tablo 6: Mobilya Sektörünün Ă̆ırlıklı Normalize Karar Matrisleri

\begin{tabular}{|c|c|c|c|c|c|c|c|c|c|c|c|c|c|c|c|c|}
\hline Yillar & L1 & L2 & L3 & M1 & M2 & M3 & M4 & V1 & V2 & V3 & V4 & K1 & $\mathrm{K} 2$ & K3 & K4 & K5 \\
\hline 2009 & 0,0201 & 0,0210 & 0,0236 & 0,0169 & 0,0225 & 0,0175 & 0,0124 & 0,0213 & 0,0219 & 0,0208 & 0,0173 & 0,0195 & 0,0222 & 0,0228 & 0,0250 & 0,0212 \\
\hline 2010 & 0,0199 & 0,0202 & 0,0237 & 0,0172 & 0,0218 & 0,0176 & 0,0127 & 0,0204 & 0,0193 & 0,0189 & 0,0162 & 0,0198 & 0,0194 & 0,0228 & 0,0223 & 0,0197 \\
\hline 2011 & 0,0190 & 0,0185 & 0,0211 & 0,0182 & 0,0200 & 0,0187 & 0,0296 & 0,0212 & 0,0191 & 0,0199 & 0,0185 & 0,0192 & 0,0188 & 0,0111 & 0,0112 & 0,0108 \\
\hline 2012 & 0,0192 & 0,0188 & 0,0189 & 0,0182 & 0,0199 & 0,0186 & 0,0153 & 0,0193 & 0,0187 & 0,0192 & 0,0180 & 0,0182 & 0,0166 & 0,0205 & 0,0210 & 0,0201 \\
\hline 2013 & 0,0188 & 0,0186 & 0,0177 & 0,0189 & 0,0186 & 0,0187 & 0,0184 & 0,0179 & 0,0182 & 0,0184 & 0,0184 & 0,0189 & 0,0188 & 0,0211 & 0,0210 & 0,0210 \\
\hline 2014 & 0,0183 & 0,0176 & 0,0167 & 0,0194 & 0,0177 & 0,0193 & 0,0190 & 0,0179 & 0,0174 & 0,0182 & 0,0192 & 0,0186 & 0,0173 & 0,0199 & 0,0191 & 0,0206 \\
\hline 2015 & 0,0178 & 0,0172 & 0,0159 & 0,0197 & 0,0170 & 0,0199 & 0,0192 & 0,0172 & 0,0165 & 0,0175 & 0,0192 & 0,0191 & 0,0194 & 0,0199 & 0,0184 & 0,0203 \\
\hline 2016 & 0,0179 & 0,0162 & 0,0135 & 0,0198 & 0,0168 & 0,0198 & 0,0196 & 0,0165 & 0,0145 & 0,0164 & 0,0182 & 0,0191 & 0,0160 & 0,0070 & 0,0059 & 0,0070 \\
\hline 2017 & 0,0185 & 0,0191 & 0,0164 & 0,0199 & 0,0167 & 0,0194 & 0,0191 & 0,0176 & 0,0191 & 0,0187 & 0,0207 & 0,0184 & 0,0197 & 0,0211 & 0,0204 & 0,0233 \\
\hline 2018 & 0,0185 & 0,0186 & 0,0154 & 0,0197 & 0,0170 & 0,0193 & 0,0196 & 0,0182 & 0,0193 & 0,0193 & 0,0212 & 0,0180 & 0,0179 & 0,0111 & 0,0112 & 0,0124 \\
\hline 2019 & 0,0192 & 0,0208 & 0,0213 & 0,0190 & 0,0183 & 0,0184 & 0,0169 & 0,0191 & 0,0220 & 0,0195 & 0,0198 & 0,0185 & 0,0203 & 0,0217 & 0,0223 & 0,0228 \\
\hline
\end{tabular}

Ağırlıklı karar matrisinin düzenlenmesinden sonraki adımda ideal $\left(\mathrm{A}^{*}\right)$ ve negatif ideal (A $\mathrm{A}^{-}$) çözümler oluşturulmuş ve çözümler Tablo 7'de gösterilmiştir.

Tablo 7: Mobilya Sektörünün İdeal ve Negatif İdeal Çözümünün Belirlenmesi

\begin{tabular}{|c|c|c|c|c|c|c|c|c|c|c|c|c|c|c|c|c|}
\hline $\mathbf{A}^{*}$ & 0,0201 & 0,0210 & 0,0237 & 0,0169 & 0,0225 & 0,0175 & 0,0296 & 0,0213 & 0,0220 & 0,0208 & 0,0212 & 0,0198 & 0,0222 & 0,0228 & 0,0250 & 0,0233 \\
\hline $\mathbf{A}^{-}$ & 0,0178 & 0,0162 & 0,0135 & 0,0199 & 0,0167 & 0,0199 & 0,0124 & 0,0165 & 0,0145 & 0,0164 & 0,0162 & 0,0180 & 0,0160 & 0,0070 & 0,0059 & 0,0070 \\
\hline
\end{tabular}

\footnotetext{
${ }^{1}$ Ağırlıklandırma vektörünün hesaplanması sırasında finansal performans kriterlerine eşit oranda ağırlık yüklenerek toplam 16 finansal oran kullanıldığı için her bir kriterin ağırlı̆̆ı $1 / 16=0,0625$ şeklinde
} hesaplanmıştır. 
Yöntemin beşinci adımında, her bir karar noktasına ait değerlendirme kriteri değeri bulunurken ideal ve negatif ideal çözüm setindeki sapmaların belirlenmesi için ayrım ölçüleri hesaplanmaktadır. İdeal ayırım $\left(\mathrm{S}_{\mathrm{i}}^{*}\right)$ ve negatif ideal ayırım $\left(\mathrm{S}_{\mathrm{i}}{ }^{-}\right)$ölçülerinin belirlenmesinden sonraki adımda ise performans sıralaması yapılmaktadır. Mobilya sektörünün 2009-2019 yılları arasındaki ideal ve negatif ideal çözümden olan uzaklıkları, yıllar itibariyle performans puanları ve performans sıralamaları Tablo 8 'de gösterilmiştir.

Tablo 8: İdeal Çözüme Göreli Yakınlı̆̆ın Hesaplanarak Performans Sıralamasının Yapılması

\begin{tabular}{|c|c|c|c|c|}
\hline Yıllar & $\mathbf{S}^{*}$ & $\mathbf{S}^{-}$ & (C) Puan & Siralama \\
\hline $\mathbf{2 0 0 9}$ & 0,0177 & 0,0336 & 1,9305 & 2 \\
\hline $\mathbf{2 0 1 0}$ & 0,0187 & 0,0300 & 1,6311 & 5 \\
\hline $\mathbf{2 0 1 1}$ & 0,0231 & 0,0224 & 0,9932 & 9 \\
\hline $\mathbf{2 0 1 2}$ & 0,0183 & 0,0260 & 1,4518 & 6 \\
\hline $\mathbf{2 0 1 3}$ & 0,0163 & 0,0268 & 1,6785 & 4 \\
\hline $\mathbf{2 0 1 4}$ & 0,0181 & 0,0246 & 1,3798 & 7 \\
\hline $\mathbf{2 0 1 5}$ & 0,0191 & 0,0241 & 1,2873 & 8 \\
\hline $\mathbf{2 0 1 6}$ & 0,0361 & 0,0075 & 0,2157 & 3 \\
\hline $\mathbf{2 0 1 7}$ & 0,0165 & 0,0282 & 1,7316 & 10 \\
\hline $\mathbf{2 0 1 8}$ & 0,0265 & 0,0141 & 0,5434 & 1 \\
\hline $\mathbf{2 0 1 9}$ & 0,0145 & 0,0308 & 2,1472 & \\
\hline
\end{tabular}

Tablo 8'de görüldüğü gibi, TOPSİS analizi sonuçlarına göre mobilya imalatı sektör performansının en iyi olduğu yıl 2019 yılı olarak belirlenmiştir. Sektörün finansal performansının en düşük olduğu yıl ise 2016 yılı olarak tespit edilmiştir.

\section{SONUÇ}

Emek yoğun bir sektör olan mobilya imalatı sektörü, insanların mobilyayı seçme aşamasında rahatlığı, estetiği ve görselliği dikkate aldığı sektörlerden biridir. Çünkü, insanların zevkleri ve istekleri farklılık göstermektedir. Bu nedenle mobilya imalatı sektöründe işletmeler standart mobilyaların yanı sıra müş̧erilere özel mobilya üretim faaliyetlerini de gerçekleştirmektedir. İşletmelerin müşteri ihtiyaçlarını onları memnun ederek karşılaması sonucunda işletmelerin finansal tabloları da bu durumdan olumlu olarak etkilenecektir. İşletmeler tarafından düzenlenen bu tabloların işletme faaliyetlerine yön verebilmesi için tabloların analiz edilmesi gerekmektedir. Analiz işlemi sonucunda elde edilen bilgiler işletme yöneticilerinin ve sektör temsilcilerinin alacakları kararlara yön vermektedir. Bu nedenle, işletme ve sektör performanslarının değerlendirilmesinde finansal tabloların analiz edilerek işletme ve sektör ile ilgili doğru kararların alınması önem taşımaktadır.

Türkiye'de mobilya imalatı sektörünün finansal performansının analiz edilerek değerlendirilmesi çalışmanın amacını oluşturmaktadır. Belirlenen amaç doğrultusunda, mobilya imalatı sektöründe faaliyet gösteren 6203 işletmenin 2009 - 2019 yılları arasındaki verileri için TCMB'nin resmi internet sitesinde yayınlanmış olan sektör bilançolarından faydalanılmıştır. Veriler oran analizi ve Topsis yöntemi aracılığı ile analiz edilmiştir. Sektöre ait oran analizi sonuçları genel kabul görmüş standart oran değerleri ile karşılaştırılarak sektörün finansal performansları ile ilgili değerlendirmelerde bulunulmuştur. $\mathrm{Bu}$ değerlendirmeler aşağıdaki gibi sıralanabilir:

- Mobilya imalatı sektörü likidite oranları açısından değerlendirildiğinde, sektörün 2009 - 2013 yılları arasında ve 2019 yılında kısa vadeli yükümlülüklerini yerine getirebilmek için yeterli düzeyde hazır değerlere sahip olduğu belirlenmiştir. Buna rağmen, nakit oranı değerleri dikkate alındığında, sektörün 2013 - 2018 yılları arasında satışlarının durması ve alacaklarını tahsil edememesi durumunda bu yükümlülüklerini yerine getirmede zorlandığı tespit edilmiştir.

- Sektör finansal yapı oranları açısından değerlendirildiğinde, mobilya imalatı sektörünün varlıklarını finanse ederken genellikle yabancı kaynaklarını kullandığı, çalışma kapsamındaki diğer yıllardan farklı olarak 2011 yılında maddi duran varlıkların finanse edilmesi aşamasında $\% 60$ oranında özkaynakların kullanıldığı belirlenmiştir. 
- Sektörün varlık kullanım oranları incelendiğinde, sektör stoklarını yılda 1,7 - 2,7 kez ve 133 214 gün aralığında yenilemekte; alacaklarını yılda ortalama 3 - 4 kez ve $88-115$ gün arasında tahsil etmektedir. Aktif devir hızı ise sektörün sahip olduğu varlıklarının altında satış yapıldığını göstermektedir. Sektörün özkaynaklarını 2010, 2012 ve 2016 yılları hariç diğer yıllarda daha verimli kullandığg tespit edilmiştir.

- Sektör kârlılık oranları açısından değerlendirildiğinde, brüt kârlılık oranının en düşük 2012 yılında diğer yıllar arasında çok büyük farklılıklar olmasa da en yüksek 2010 yılında oluştuğu belirlenmiştir. Sektördeki pazarlama, satış ve dağıtım giderlerinin her geçen yıl artış göstermesinden dolayı faaliyet kâr marjı düşük seviyededir. Sektörün çalışma kapsamındaki tüm yıllarda düşük de olsa kâr ettiği tespit edilmiştir.

- Mobilya imalatı sektöründeki oran değerleri kullanılarak yapılan Topsis analizi sonuçları değerlendirildiğinde, sektör performansının en iyi olduğu yıl 2019 yılı, en düşük seviyede olduğu yıl ise 2016 yılı olarak belirlenmiştir.

Çalışmadan elde edilen sonuçlara göre mobilya imalatı sektörünün likidite oranlarındaki dalgalanmalardan dolayı yöneticiler, yükümlülüklerini karşılayabilecek ve faaliyetlerini devam ettirebilecek şekilde likit varlık yatırımlarını gerçekleştirmelidir. Sektördeki kârlılığın arttırılabilmesi amacıyla maliyet ve gelir kalemleri doğru bir şekilde analiz edilmeli ve gelir kalemlerini arttırıcı, maliyetleri azaltıcı yönde faaliyetler geliştirilmelidir. Elde edilen sonuçlar mobilya imalatı sektörünün mevcut yatırımcılarına, bu sektöre yatırım yapmak isteyen kişilere, sektör temsilcilerine ve bu sektör ile ilgili kişilere alacakları kararlarda yardımcı olabilecektir.

\section{KAYNAKÇA}

Akbulut, R. ve Rençber, Ö. F. (2015). "Bist'te İmalat Sektöründeki İşletmelerin Finansal Performansları Üzerine Bir Araştırma”, Muhasebe ve Finansman Dergisi, 65, 117 - 136.

Akdoğan, N. ve Tenker, N. (2007). Finansal Tablolar ve Mali Analiz Teknikleri, Ankara: Gazi Kitabevi. Akgüç, Ö. (1998). Finansal Yönetim, İstanbul: Avcıol Basım Yayın.

Akyüz, K. C.; Yıldırım, İ. ve Akyüz, İ. (2017). "Yüzde Yöntemi ve Bazı Finansal Oranlar Yardımıyla Orman Ürünleri Sanayi Sektöründe Yer Alan Firmaların Değerlendirilmesi”, İleri Teknoloji Bilimleri Dergisi, 6(3), $93-101$.

Aytekin, S. ve Sakarya, Ş. (2013), “BIST'de İşlem Gören Gıda İşletmelerinin TOPSIS Yöntemi ile Finansal Performanslarının Değerlendirilmesi, Yönetim ve Ekonomi Araştırmaları Dergisi, 21, 30 - 47.

Baba, M. C. (2017). "Financial Reporting in the Furniture Industry", Bulletin of the Transilvania Univarsity of Braşov Series V: Economics Seciences 10(59), 179 - 186.

Bilici, N. (2019). "Turizm Sektörünün Finansal Performansının Oran Analizi ve TOPSIS Yöntemiyle Değerlendirilmesi”, Atatürk Üniversitesi Sosyal Bilimler Enstitüsü Dergisi, 23(1), 173 - 194.

Burja, V. and Marginean, R. (2014). "The Study of Factors That may Influence the Performnace by the Dupont Analysis in the Furniture Industry", Procedia Economics and Finance 16, 213 - 223.

Chen, C.T. (2000), "Extensions of the TOPSIS for Group Decision - Making Under Fuzzy Environment", Fuzzy Sets and Systems, 114, $1-9$.

Çabuk, A. ve Lazol, İ. (2009). Mali Tablolar Analizi, Bursa: Ekin Kitabevi.

Deran, A.; İskenderoğlu, Ö. ve Erduru, İ. (2014). "Regional Differences and Financial Ratios: A Comparative Approach on Companies of ISE City Indexes" International Journal of Economics and Financial Issues, Vol. 4, No. 4, pp. 946 - 955.

Dashti, Z.; Pedram, M. M. and Shanbehzadeh, J. (March 17 - 19, 2010). "A Multi - Criteria Decision Making Based Method for Ranking Sequential Patterns", Proceedings of the International Multi Conference of Engineers and Computer Scientists Vol I, Hong Kong. 
Eyüboğlu, K. ve Bayraktar, Y. (2019), “Ana Metal Sanayi Alt Sektörlerinin Finansal Performanslarının AHP ve TOPSIS Yöntemleri İle Değerlendirilmesi”, Muhasebe ve Finans İncelemeleri Dergisi, 2(1), 1 -10 .

Jahanshahloo, G. R., Lotfi, F. H. and Izadikhah, M. (2006), "Extension of the TOPSIS Method for Decision - Making Problems with Fuzzy Data", Applied Mathematics and Computation, 181, 1544 1551.

Kızılbudak, T. (2013) "Finansal Analiz İle İşletme Sermayesi Yönetimi: Mobilya Sektörü İçin Bir Uygulama", T.C. Maltepe Üniversitesi Sosyal Bilimler Enstitüsü İşletme Anabilim Dalı, Yayınlanmamış Yüksek Lisans Tezi, İstanbul.

Mashkour, S. C. (2019). "Financial Ratios Analysis", Analysis of Financial Statements, Iraq: AlAlalamia for Printing and Designs Sammawa. 1-30.

Moch, R.; Prrhatn1, R. and Buchdad1, A. D. (2019). “The Effect of Liquidity, Profitability and Solvability to the Financial Distress of Manufactured Companies Listed on the Indonesia Stock Exchange (IDX) Period of Year 2015 - 2017", Academy of Accounting and Financial Studies Journal, 23(6), 1 - 16.

Mutlu, O. A; Yılmaz, A. ve Başer, B. C. (2012). TR81 Düzey2 Bölgesi Mobilya ve Orman Ürünleri Sektör Analizi Raporu, Batı Karadeniz Kalkınma Ajansı, Zonguldak: İnnocentric.

Okka, O. (2006). Finansal Yönetime Giriş, Ankara: Nobel Yayın Dağıtım.

Olson, D. L. (2004), "Comparison of Weights inTOPSIS Models", Mathematical and Computer Modelling, 40, $721-727$.

Opricovic, S. and Tzeng, G-H. (2004), "Compromise Solution by MCDM Methods: A Comparative Analysis of VIKOR and TOPSIS”, European Journal of Operational Research, (156), 445 - 455.

Ömürbek, V. ve Kınay, B. (2013). "Havayolu Taşımacılığı Sektöründe TOPSIS Yöntemiyle Finansal Performans Değerlendirmesi”, Süleyman Demirel Üniversitesi İktisadi ve İdari Bilimler Fakültesi Dergisi, 18(3), 343 - 363.

Ömürbek, N. ve Mercan, Y. (2014). "İmalat Alt Sektörlerinin Finansal Performanslarının TOPSİS ve ELECTRE Yöntemleri ile Değerlendirilmesi”, Çankırı Karatekin Üniversitesi İktisadi ve İdari Bilimler Fakültesi Dergisi, 4(1), 237 - 266.

Öztel, A. ve Yavuz, H. (2019). "Entropi Tabanlı Topsis Yöntemi ile Finansal Performans Analizi: Mobilya ve Ağaç İşleri Sektörlerinde Bir Uygulama”, 5. Uluslararası Ekonomi Yönetimi ve Pazar Araştırmaları Kongresi, İstanbul: Güven Plus Grup A.Ş. Yayınları, 176 - 184

Stepanyan, A. (2014). "Traditional Ratio Analysis in the Airline Business: A Case Study of Leading U.S Carriers", International Journal of Advances in Management and Economics, 3(2), 175 - 189.

Traian - Ovidiu, C. (2013), "Case Study on Analysis of Financial Statements at a Furniture Manufacturer", Journal of Knowledge Management, Economics and Information Technology, III(5), 1 -24 .

Türkiye Cumhuriyet Merkez Bankas1, Sektör Bilançoları, http://www3.tcmb.gov.tr/sektor/2020/\#/tr/C/imalat, (Erişim Tarihi: 25.12.2020)

Uludağ, A. S. ve Doğan, H. (2016), “Çok Kriterli Karar Verme Yöntemlerinin Karşılaştırılmasına Odaklı Bir Hizmet Kalitesi Uygulaması" Çankırı Karatekin Üniversitesi İktisadi ve İdari Bilimler Fakültesi Dergisi, 6(2), 17 - 47.

Uygurtürk, H. ve Korkmaz, T. (2012). "Finansal Performansın TOPSIS Çok Kriterli Karar Verme Yöntemi İle Belirlenmesi: Ana Metal Sanayi İşletmeleri Üzerine Bir Uygulama”, Eskişehir Osmangazi Üniversitesi İ̈BF Dergisi, 7(2), 95 - 115.

Uzun, S. ve Kazan, H. (2016). "Çok Kriterli Karar Verme Yöntemlerinden AHP TOPSIS ve PROMETHEE Karşılaştırılması: Gemi İnşada Ana Makine Seçimi Uygulaması", Journal of Transportation and Logistics, 1(1), $99-113$. 